\title{
Guillain Barre Syndrome pada Kehamilan
}

\author{
Hermin Sabaruddin ${ }^{1}$, Pribakti Budinurdjaja ${ }^{2}$, Fakhrurrazy ${ }^{3}$ \\ Program Pendidikan Dokter Spesialis Obstetri dan Ginekologi ${ }^{1}$ \\ Dokter Spesialis Obstetri dan Ginekologi RSUD.Ulin Banjarmasin ${ }^{2}$ \\ Dokter Spesialis Saraf RSUD.Ulin Banjarmasin ${ }^{3}$ \\ Fakultas Kedokteran Universitas Lambung Mangkurat \\ *e-mail: hermin.obsgyn.ulm17@gmail.com
}

\begin{abstract}
Abstrak
Guillain-Barre Syndrome (GBS) merupakan sindroma klinis yang ditandai adanya paralisis flaksid dan terjadi secara akut. GBS berhubungan dengan reaksi autoimun yang menyerang saraf perifer, radiks, dan nervus kranialis. Insiden GBS adalah 1-2 per 100.000 orang/tahun. Insiden meningkat seiring dengan pertambahan umur dan meningkatnya populasi obstetrik. GBS yang terjadi pada kehamilan bervariasi, mulai dari $13 \%$ pada trimester pertama, $47 \%$ pada trimester kedua, dan $40 \%$ pada trimester ketiga. Pada laporan kasus ini dilaporkan Ny. M berusia 27 tahun dengan diagnosis G2P1A0 H.39-40 minggu+ janin tunggal hidup intrauterin + Presentasi Kepala + Inpartu kala II +GBS+ Gagal Vakum + Severily Underweight $(\mathrm{BMI}=17)+\mathrm{TBJ}$ 3000 gr. Diagnosis GBS ditegakkan berdasarkan anamnesis, pemeriksaan fisik dan pemeriksaan penunjang. Anamnesis ditemukan riwayat penyakit sebelumnya kelemahan anggota gerak sejak tahun 2016. Riwayat penggunaan alat bantu nafas dan masuk ICU saat hamil anak 1, memiliki riwayat infeksi sebelum pasien didiagnosis GBS. Pada kehamilan kedua ini pasien tidak dapat menggerakkan ektremitas bawah namun ektremitas atas dapat digerakkan. Dari hasil pemeriksaan fisik ibu dan bayi dalam batas normal walaupun ditemukan BMI dalam kondisi severily underweight. Pasien akhirnya diputuskan untuk SC (section caesaria) dan pemasangan IUD (intrauterine divice) intracaesarean GBS pada kehamilan merupakan suatu koinsidental. GBS jarang memperberat kehamilan, namun jika tidak cepat teridentifikasi dan ditangani dapat meningkatkan tingginya morbiditas pada ibu dan janin. Pada serangan akut (AIDP) acute inflammatory demyelinating polyradiculopathy pada ibu hamil dengan GBS, dapat meningkatkan stres pada ibu maupun janin. Stres yang terjadi juga dapat merangsang sistem imun memproduksi prostaglandin sehingga mengakibatkan terjadinya persalinan prematur. Pasien dapat melahirkan saat usia kehamilan masih 7 bulan. Berbeda pada kehamilan kedua pada kasus ini dimana pasien didiagnosis dengan chronic inflammatory demyelinating polyradiculopathy (CIDP) sehingga GBS tidak mempengaruhi ibu dan janin.
\end{abstract}

Kata Kunci: auitomun, Guillain- Barre Syndrome, kehamilan.

\section{Guillain Barre Syndrome in Pregnancy}

\begin{abstract}
Guillain-Barre Syndrome (GBS) is a clinical syndrome characterized by the presence of the complete flaksid that occurs in acute. GBS associated with autoimmune reaction that affect peripheral nerve, radix, and cranial nerve. The incidence of GBS is $1-2$ per 100,000 people/year. The incident was followed by increased age and the increasing population of obstetrics. GBS in pregnancy ranged from $13 \%$ in the first trimester, $47 \%$ in the second
\end{abstract}


trimester, and $40 \%$ in the third trimester. In this case report reported Mrs. $M 27$ years old with a diagnosis of G2P1AO h. 39-40 weeks + insimanation + living single fetal Presentation Head + Inpartu kala II + GBS + Failed + Vacuum Severily Underweight $(B M I=17)+T B J 3000$ Gr. Diagnosis of GBS are enforced based on anamnesis, physical examination and complementary examinations. From a previous illness history found anamnesis the weakness of limbs beginning in 2016. A history of the use of breathing apparatus and admitted tot the ICU in the first pregnancy. Mrs. $M$ had a history of infections before being diagnosed with GBS. On this second pregnancy patients cannot move lower extremity but upper extermity is still functioning. Physical examination result of mothers and babies in the normal range even though found in conditions of severily BMI underweight. The patient finally decided to SC (section caesaria) and applied the IUD intracaesarean GBS in pregnancy is a coincidental. GBS is rarely aggravate pregnancy, but if not quickly identified and handled can enhance the high morbidity in both mother and fetus. In acute attacks (AIDP) in pregnant women with GBS increase stress on the mother or the fetus. The stress that occurs can also stimulate the immune system to produce prostaglandins, resulting in premature birth. Patients can give birth when the gestational age is still 7 months. It was different in the second pregnancy in this case where the patient was diagnosed with chronic inflammatory demyelinating polyradiculopathy (CIDP) so that GBS did not affect the mother and the fetus.

Keywords: autoimmine, Guillain-Barre Syndrome, Pregnancy.

\section{PENDAHULUAN}

Guillain-Barre Syndrome (GBS) adalah suatu penyakit kelemahan lesi Lower Motor Neuron (LMN). LMN ini sering ditemukan pada usia dewasa muda dan dapat menimbulkan kematian. GBS merupakan penyakit neuropathy yang disebabkan oleh reaksi autoimmune sehingga dapat mengganggu fungsi motorik dan fungsi sensorik seperti perasa nyeri, suhu, dan perabaan. GBS dapat menimbulkan kelemahan otot pada ekstremitas dan hilangnya fungsi sensorik pada kedua ekstremitas (Torricelli, 2017; Fokke et al, 2014).

Insiden GBS adalah 1-2 per100.000 orang/tahun. Insiden meningkat diikuti pertambahan umur dan meningkatnya populasi obstetrik. Di Eropa dan Amerika Utara, kasus terbanyak pada tipe polineuropati demielinasi inflamasi akut sedangkan di Asia, Selatan dan Tengah Amerika paling sering subtipe neuropati motorik akson akut. GBS pada kehamilan bervariasi mulai dari $13 \%$ pada trimester pertama, $47 \%$ pada trimester kedua, dan $40 \%$ pada trimester ketiga. Penyakit ini juga dapat terjadi pada periode post partum dan masa nifas. Hal ini pernah dilaporkan Van Doorn pada 30 kasus pasien hamil terdapat peningkatan insidensi pada periode postpartum (Hiraga et al, 2016; Cheng et al, 2016).

\section{Guillain-Barre Syndrome GBS yang} timbul bersamaan dengan kehamilan merupakan suatu koinsidental. GBS secara umum tidak dipengaruhi oleh kehamilan 
demikian sebaliknya kehamilan tidak dipengaruhi oleh GBS. Bayi yang lahir dari pasien yang menderita GBS umumnya tidak terpengaruh. Pemberian plasmapheresis cukup aman selama kehamilan, khususnya ibu hamil dengan disfungsi autonomic. Pemberian plasmapheresis ini sensitif terhadap perubahan dalam volume plasma. Angka kekambuhan "chronic inflammatory demyelinating polyneuropathy" diperkirakan tiga kali lebih besar" pada trimester ketiga kehamilan dan puerperium (Torricelli, 2017; Fokke et al, 2014).

Pada laporan kasus ini dilaporkan Ny. M berusia 27 tahun dengan diagnosis G2P1AO H.39-40 minggu+ janin tunggal hidup intrauterin + Presentasi Kepala + Inpartu kala II +GBS+ Gagal Vakum+ Severily Underweight $(\mathrm{BMI}=17)+\mathrm{TBJ}$ 3000 gr. Diagnosis GBS ditegakkan berdasarkan anamnesis, pemeriksaan fisik dan pemeriksaan penunjang. Dari anamnesis ditemukan riwayat penyakit sebelumnya kelemahan anggota gerak sejak tahun 2016. Riwayat penggunaan alat bantu nafas dan masuk ICU saat hamil anak 1. Dan riwayat infeksi sebelum pasien didiagnosis GBS.

Pada kehamilan kedua ini pasien tidak dapat menggerakkan ektremitas bawah namun, ektremitas atas dapat digerakkan. Dari hasil pemeriksaan fisik ibu dan bayi dalam batas normal ditemukan BMI dalam kondisi severily underweight. Pasien dikonsulkan di bidang Neurologi dan didiagnosis Obs. Paraparesis ec CIDP (Chronic Inflammatory Demyelinating Polyneuropathy), disarankan pemberian Inj. Mecobalamin 1x500 mg dan tidak ada kontra indikasi untuk mengejan. Pada perjalanannya pasien tidak dapat mengejan, dicoba untuk vakum ekstraksi namun gagal. Pasien akhirnya diputuskan untuk SC (section caesaria) dan pemasangan IUD intracaesarean. Lahir bayi laki-laki dengan berat badan 3000 gr, panjang badan $47 \mathrm{~cm}$ dengan apgar score 6-7-8. Bayi dirawat diruang perinatologi selama 1 hari kemudian rawat gabung. Pasien dipulangkan setelah dirawat selama 3 hari post SC dalam keadaan tidak ada keluhan, status umum dan status obstetrik dalam batas normal.

\section{PRESENTASI KASUS}

\section{Identitas Pasien}

$\begin{array}{ll}\text { Nama } & : \text { Ny. M } \\ \text { No Medrec } & : 1390543 \\ \text { Umur } & : 27 \text { tahun } \\ \text { Alamat } & : \text { Jl. Pamurus dalam } \\ & \text { tembikar kanan RT 11 No. } \\ & 81 \\ \text { MRS } & : \text { Tgl. 01 Juli } 2018 \text { pkl. 03.00 } \\ & \text { WITA }\end{array}$




\section{Anamnesis}

Pasien datang diantar suami dengan keluhan keram perut sampai ke punggung sejak 7 jam SMKB, lendir darah (+) 6 jam SMKB, keluar air-air (-), gerak janin (+). Pasien mengaku menderita GBS sejak 2016 saat hamil anak pertama umur kehamilan 7 bulan dan tidak dapat menggerakkan kedua kakinya. R/ MRS sebelumnya tgl 25 Mei 2018 dengan G2P1A0 H. 33-34 mggu + Tak Inpartu + GBS + PPI. Pasien saat itu diberi tokolitik dan pematangan paru selama $2 \times 24$ jam, pasien dikonsul ke bagian saraf dan diberi inj. mecobalamin $1 \times 500 \mathrm{mg}$ dan dikatakan tidak ada kontra indikasi untuk terminasi pervaginam. Riwayat kontrol kehamilan $2 x$ di bidan praktek mandiri dan tidak pernah kontrol ke dokter spesialis kandungan.

Berdasarkan Haid Pertama Haid Terakhir Tanggal 30-09-2017 dengan taksiran kelahiran 07-07-2018, usia kehamilan saat itu 39-40 minggu. Riwayat melahirkan dari Pasien, sebelumnya adalah bayi kembar dengan spontan kepala dengan umur kehamilan 7 bulan dengan berat badan bayi $1700 \mathrm{~g} / 1500 \mathrm{~g}$ pada tahun 2017 . Ini merupakan kehamilan kedua dan pasien masih dalam keadaan lemah kedua kaki. Riwayat pernikahan $1 x$ selama 4 tahun. Tidak ada riwayat KB sebelumnya.

\section{Perjalanan penyakit sebelumnya:}

\section{September 2016}

Pada kehamilan pertama pada bulan September 2016 pasien mengaku demam, batuk pilek selama seminggu, pasien didiagnosis ISPA. Saat itu pasien hamil umur kehamilan 6 bulan. Satu minggu setelah demam, batuk dan pilek pasien mengaku tidak dapat menggerakkan kedua kakinya dan beberapa lama kemudian kedua tangan tidak bisa digerakkan. Saat itu pasien ke RS. Ulin dan didignosa GBS. Pasien dalam keadaan sesak dan dirawat di ICU RS. Ulin. Pasien mengaku melahirkan prematur dengan umur kehamilan 7 bulan. Post rawat pasien disarankan melakukan 4 tahapan fisioterapi (Biofeedback, IR + TENS, ROM exeras, breathing exercise) namun pasien hanya melakukan fisioterapi sebanyak $4 x$

\section{Mei 2018}

Pasien datang diantar suami karena merasa sudah waktunya melahirkan. Pasien lupa haid pertama haid terakhir. Pasien saat itu mengeluh keram perut (-), lendir darah (-), keluar air ketuban maks (-), gerak janin (+). Pasien di diagnosis dengan G2P1A0 minggu+JTHIU+PPI+GBS+TBJ 1800 g. Pasien ditatalaksana dengan pematangan paru dan pemberian tokolitik selama $2 \times 24$ jam. 
Jawaban Konsul saraf Tgl 25-05-2018:

Pada pemeriksaan neurologis

$\mathrm{KU}$ : lemah, CM E4V5M6

Pada ekstremitas motorik

\begin{tabular}{l|l}
5 & 5 \\
\hline 2 & 2
\end{tabular}

\section{Refleks Fisiologis}

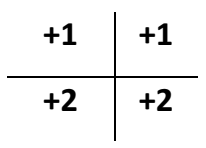

\section{Atrofi}

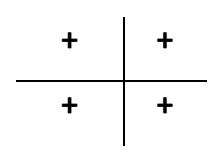

Refleks Patologis

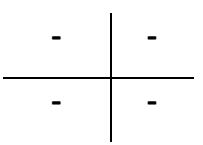

Assesment: Obs. Paraparesis ec CIDP (Chronic Inflammatory Demyelinating Polyneuropathy)/ GBS

Saran: Inj. Mecobalamin 1x500mg

Lain-lain Terapi TS obgyn

Tidak ada kontraindikasi tindakan pervaginam

\section{Pemeriksaan Fisik}

Pemeriksaan status umum pasien dalam kedaan sadar tidak ada anemia, ikterik, cianosis dan dyspnoe. Dari tanda vital dalam batas normal. Pemeriksaan jantung dan paru dalam batas normal, dari eksterimitas bawah didapatkan tidak terdapat refleks patologis, reflek fisiologis
$(+/+)$, atrofi $(+/+)$. Dari Body Mass Index sebesar 17 (severily underweight). Dari status obstetri didapatkan tinggi fundus uteri sebesar $31 \mathrm{~cm}$ dengan bayi berada di punggung kiri dengan presentasi kepala sudah masuk PAP (pintu atas panggul). Denyut jantung bayi $144 \mathrm{x} / \mathrm{mnt}$ dengan taksiran berat janin $3000 \mathrm{~g}$ dengan His $3 \mathrm{x}$ dalam 10 menit dalam 30 detik. Pada pemeriksaan dalam ditemukan pembukaan $6 \mathrm{~cm}$, penipisan $75 \%$, ketuban $(+)$, kepala, ubun-ubun kecil kiri depan berada di HII.

\section{Pemeriksaan Penunjang}

\section{Pada pemeriksaan laboratorium}

didapatkan hasil yang normal dengan nilai $\mathrm{Hb} 11,8 \mathrm{~g} / \mathrm{dl}$ dengan sel darah putih 9.3 ribu/ul, trombosit 373 ribu/ul, Hematokrit 38,6, dengan $\mathrm{MCV} 78,2, \mathrm{MCH} 23,8, \mathrm{MCHC}$ $30,5 \%$.

Hasil faktor pembekuan darah dalam batas normal dengan nilai PT 9,9 dan APTT 18,1. Hasil pemeriksaan Hbs Ag didapatkan non reaktif.

Riwayat pemeriksaan penunjang

- Hasil MRI Cervical (Tgl 29 Juni 2016): Myelitis

- Hasil pemeriksaan Nueuro Elektromedik (Tgl 10 September 2016): Polineuropati ringan berat N. Peroneus, N. Medianus, dan N. Ulnair dengan Radikulopati Berat, Saran: Lumbal pungsi untuk melihat disosiasi sito protein (tidak 
dilakukan dengan alasan dalam keadaan hamil)

Dari pemeriksaan Kardiotokografi (Gambar

1) didapatkan hasil kategori I dengan nilai baseline : $150 \mathrm{dpm}$, variabilitas 5-25 dpm, terdapat akselerasi, tidak ada deselerasi, gerak janin (+), tidak ada his.

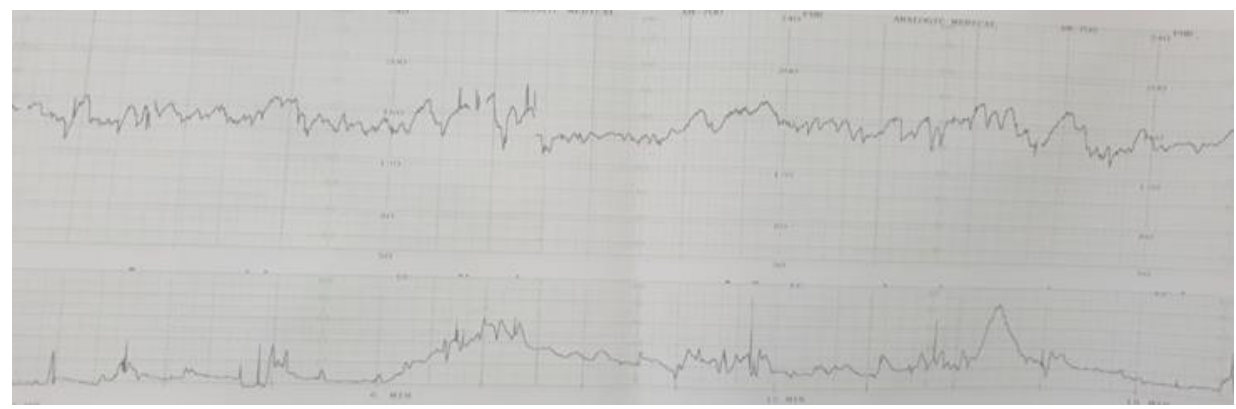

Gambar 1. Kardiotokografi

Dari hasil pemeriksaan usia kehamilan 38-39mgg, dan Abdominal Ultrasonografi di VK bersalin (Gambar 3) circumference $33,4 \mathrm{~cm}$ sesuai dengan usia didapatkan hasil Janin tunggal presentasi kehamilan 38mgg. EFW 3157 gr. Plasenta kepala dengan detak jantung janin (+), terletak di fundus, grade 2, dengan air Biparietal diameter 9,32 cm sesuai dengan ketuban yang cukup.

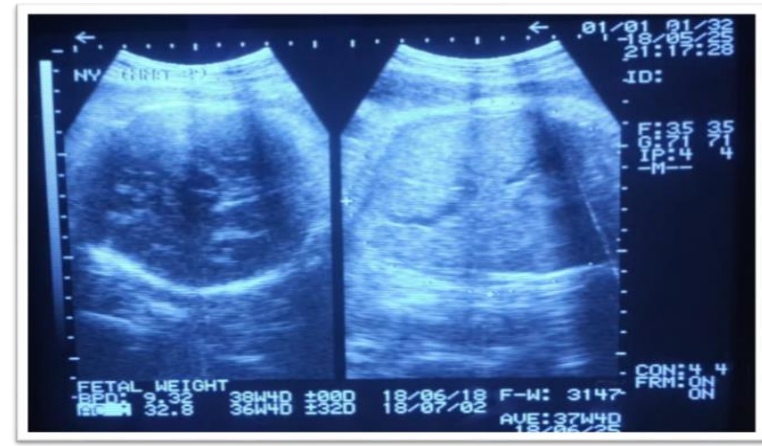

Gambar 2. Ultrasonografi di VK RSUD Ulin Banjarmasin pada tanggal 01 Juli 2018
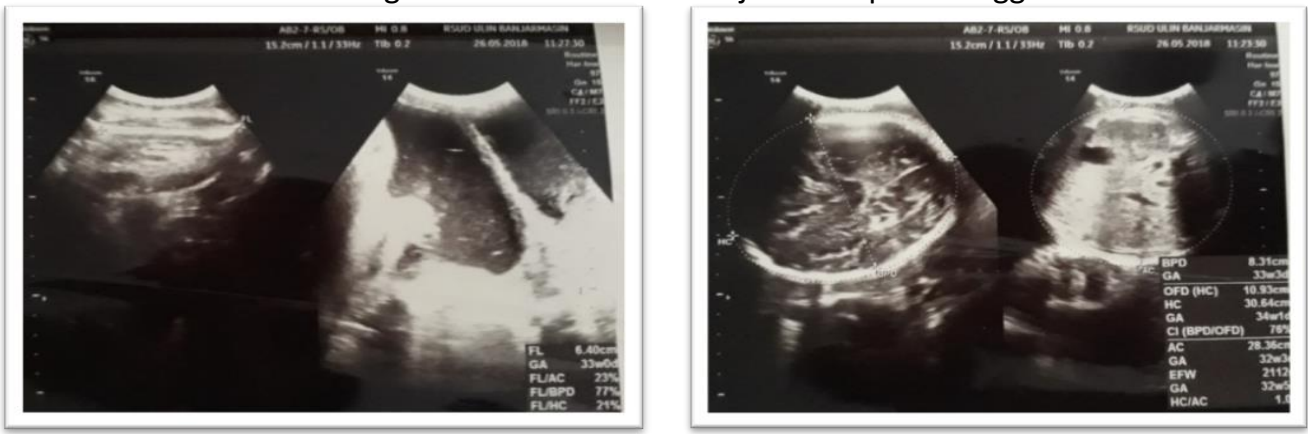

Gambar 3.Ultrasonografi Sp.OG di VK Bersalin pada perawatan sebelumnya tanggal 26 Mei 2018 
Interpretasi hasil USG :

Janin: tunggal, hidup, intrauterine, presentasi kepala

Amnion: AFI cukup

Plasenta: Implantasi di corpus posterior grade $/ / \mathrm{t}$

Biometri:

BPD $8.32 \sim 33-34$ minggu

HC 30.64 33-34 minggu

AC $28.36 \sim 33-34$ minggu

FL $6.40 \sim 33-34$ minggu

TBJ : $2112 \mathrm{gr}$

Jantung: HR 126x/menit

Anomali: saat ini tidak ada ditemukan

kelainan kongenital mayor

Lain-lain: Jenis kelamin laki-laki

Kesimpulan: Janin tunggal hidup presentase kepala, sesuai umur kehamilan 33-34 mgg, amnion kesan cukup dengan plasenta implantasi di corpus posterior

Diagnosis

Pasien didiagnosis dengan G2P1AO H 39-40 minggu + Janin Tunggal Hidup Intrauterin + Presentasi Kepala + Anemia (Hb 9,6) + GBS + Severily Underweight (BMI 17) + Inpartu kala I Fs.Aktif + Taksiran Berat Janin 3000 gr.

\section{Tatalaksana}

Pasien ditatalaksana dengan pemberian infus RL 20 tetes permenit, Pasien cek DL, PT,APTT, HBSAg, observasi cortonan, penurunan, his dan bundle, evaluasi 2 jam
Pro Spontan Belakang Kepala, Waspada HPP $\rightarrow$ pesan WB 2 kolf

\section{Evaluasi di Kamar Bersalin}

\section{Tgl 01-07-2018 Pkl. 05.00 WITA}

Subjektif : Ibu ingin mengedan, ketuban pecah spontan

Objektif : Status umum dalam batas normal, dengan status obstetric didapatkan His 5x dalam 10 menit dalam 60 detik, dengan DJJ 154 x/mnt. Dari pemeriksaan dalam didapatkan pembukaan lengkap dengan ketuban (-) jernih, bagian terbawah kepala dengan ubun ubun kecil depan berada di HIII Diangnosis pasien dengan G2P1AO H.39-40 minggu+ Janin Tunggal Hidup Intreuterine + PresKep+ GBS+ Anemia (Hb 9,6) +Severily Underweight (BMI 17)+ Inpartu kala II +TBJ $3.000 \mathrm{gr}$

Tatalaksana dengan ibu dipimpin mengejan Tgl 01-07-2018 Pkl. 06.00 WITA

Subjektif : Ibu kelelahan

Objektif : Status umum dalam batas normal, dengan status obstetric didapatkan His 3x dalam 10 menit dalam 60 detik, dengan DJJ 154 x/mnt. Dari pemeriksaan dalam didapatkan pembukaan lengkap dengan ketuban (-) jernih, bagian terbawah kepala dengan ubun ubun kecil depan berada di HIII Diagnosis pasien dengan G2P1AO H.39-40 minggu+ Janin Tunggal Hidup Intreuterine + PresKep + GBS+ Anemia (Hb 9,6) + 
Severily Underweight (BMI 17)+ Inpartu kala II + Ibu kelelahan +TBJ 3.000 gr

Tatalaksana dengan pro vakum ekstraksi, KIE keluarga $\rightarrow$ setuju

\section{Tgl 01-07-2018 Pkl. 06.30 WITA}

Subjektif : Ibu sudah tidak bisa mengejan

Objektif : Status umum dalam batas normal, dengan status obstetric didapatkan His $3 x$ dalam 10 menit dalam 60 detik, dengan DJJ 100 x/mnt. Dari pemeriksaan dalam didapatkan pembukaan lengkap dengan ketuban (-) jernih, bagian terbawah kepala dengan Ubun ubun kecil depan berada di HIII Diagnosis pasien dengan G2P1AO H.39-40 minggut janin tunggal hidup intreuterine+PresKep+GBS+Anemia $\quad(\mathrm{Hb}$ 9.6)+Gagal Vakum+ Severily Underweight (BMI 17) + Arrest of descent ec power + lbu kelelahan + TBJ $3.000 \mathrm{gr}$

Tatalaksana dengan pro Cito SC+IUD, KIE keluarga $\rightarrow$ setuju

\section{Evaluasi di Ruangan}

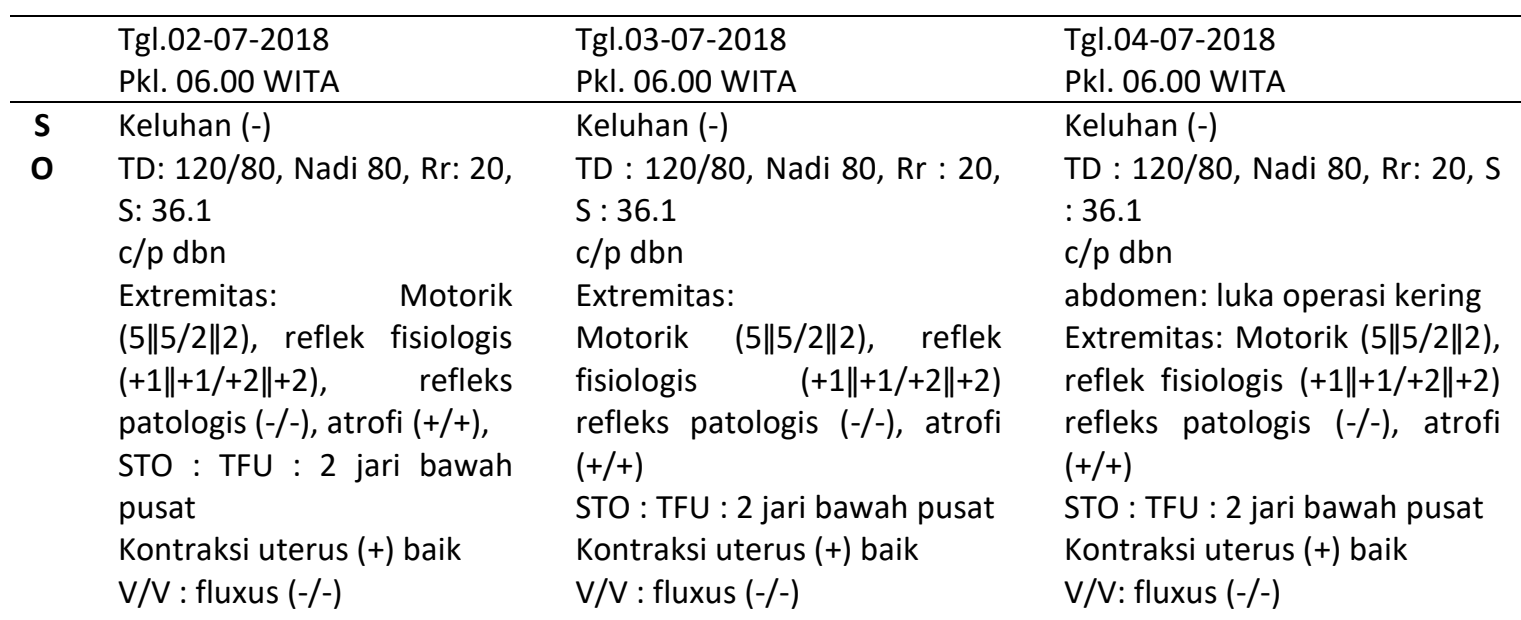

\section{Tgl 01-07-2018 Pkl. 08.05 WITA}

Lahir bayi dengan SC dan dilakukan pemasangan IUD intracaesarean, dengan Jenis kelamin Laki-laki berat badan 3000 gram panjang badan $47 \mathrm{~cm}$ dengan apgar score 6-7-8. Ballard score sesuai 38-40 dengan Lubchenco Score p50.

Pasien didiagnosis dengan P2AO post SC+IUD ai Arrest of descent ec power + Gagal vakum + GBS, Neonatal Cukup Bulan Sesuai Masa Kehamilan (SMK)

Terapi post SC:

- IVFD RL: D5: 2: 1 /24 jam

- Drip Oxytocin 1x24 jam dalam RL $500 \mathrm{cc} \mathrm{s} / \mathrm{d} 24 \mathrm{jam}$

- Inj. Ceftriaxone 2x1 g

- Inj. Furamin 3x 25 mg iv

- Inj. Asam tranexamat 3×500 mg iv

- Inj. Ranitidin 2x50mg iv

Hb post SC: $10.8 \mathrm{~g} / \mathrm{dl}$ 


\begin{tabular}{|c|c|c|c|}
\hline A & $\begin{array}{l}\text { P2A0 post SC+IUD (H1) ai } \\
\text { arrest of descent ec } \\
\text { power+Gagal vakum+GBS }\end{array}$ & $\begin{array}{l}\text { P2A0 post SC+IUD (H2) ai } \\
\text { arrest of descent ai power + } \\
\text { Gagal vakum + GBS }\end{array}$ & $\begin{array}{l}\text { P2A0 post SC+IUD (H3)+ arrest } \\
\text { of descent ec power + Gagal } \\
\text { vakum+GBS }\end{array}$ \\
\hline & Inj. Ceftriaxone $2 \times 1$ g ( $\mathrm{H} 2)$ & Inj.Ceftriaxone 2x1 g (H3) & Po cefadroxil 2x500 mg \\
\hline & $\begin{array}{l}\text { Po As. mefenamat } 3 \times 500 \\
\mathrm{mg}\end{array}$ & $\begin{array}{l}\text { Po asam mefenamat } 3 \times 500 \\
\text { mg }\end{array}$ & $\begin{array}{l}\text { Po asam mefanamat } 3 \times 500 \mathrm{mg} \\
\text { Po Sf } 2 \times 1\end{array}$ \\
\hline & Po SF $2 \times 1$ & Po SF $2 \times 1$ & Pro KRS \\
\hline
\end{tabular}

\section{Evaluasi Bayi}

\section{Tgl 01-07-2018 Pkl. 06.00 WITA}

Subjektif : Bayi gerak aktif (+)

Objektif : HR : $140 \mathrm{x} / \mathrm{mnt}$, RR 30, Suhu : $36 \mathrm{C}$,

Diagnosis : BCB SMK SC ai arrest of descent ec power+gagal vakum+GBS

Tatalaksana: Obs caput (+)

Inj. Vit K, Zalf mata

Termoregulasi, Imunisasi

\section{PEMBAHASAN}

GBS merupakan AFP Acute Flaccid Paralysis yang lesinya terletak pada radix/nervus perifer. Acute Flaccid Paralysis (AFP) merupakan kelemahan otot yang bersifat akut (AIDP) dan kronik (CIDP). GBS pada kehamilan jarang terjadi, namun dari beberapa kasus yang dilaporkan oleh Misai dkk dilaporkan seorang wanita umur 16 tahun yang mengidap GBS dalam kehamilan terjadi progresif penyakit paralisis pada saluran nafas bagian atas. GBS juga merupakan kondisi kehamilan dimana terjadi progresifitas ascending polyneuropathy (Zafar et al, 2013). Kasus lain dilaporkan oleh Sadaqat dkk yang seorang wanita hamil umur 29 tahun yang mengidap GBS merasakan nyeri dan kelemahan ekstremitas bawah pada trimester 3 kehamilan (Mori et al, 2012). Progresifitas GBS dengan gejala kelemahan motorik berlangsung cepat, maksimal dalam 4 minggu, 50\% mencapai puncak dalam 2 minggu, 80\% dalam 3 minggu, dan 90\% dalam 4 minggu dan relatif simetris.

Penegakan diagnosis GBS pada kasus Ny. M umur 27 tahun dari anamenesis ditemukan pasien tidak dapat menggerakkan kedua kakinya sejak hamil anak pertama September 2016 dan berlangsung sampai kehamilan anak kedua. Hal ini sesuai dengan gejala pada Chronic Inflammatory

Demyelinating Polyneuropathy dimana terdapat kelemahan anggota gerak yang terjadi $>3$ bulan setelah fase akut dan sering pada trimester ketiga kehamilan dan post partum (Torricelli, 2017; Gunawan et al, 2004). Dari riwayat penyakit sebelumnya pasien tahun 2016 sudah mengalami kelumpuhan kedua kaki diikuti 
kelumpuhan kedua tangan. Hal ini sesuai dengan dengan gejala klinis dari GBS yaitu memiliki gejala kelumpuhan pada kedua ekstremitas bawah bilateral berupa hypo/areflexia. Hal ini sesuai dengan kriteria diagnosis GBS dari ASBURY yaitu terdapat progresifitas kelemahan pada lengan dan kaki, arreflexia/hypoeflexia. Gejala yang mendukung diagnosis yaitu progresifitas penyakit berlangsung cepat sampai 4 minggu, relatif simetris, gangguan sensibilitas ringan, gangguan saraf kranial \pm $50 \%$ terjadi parese $\mathrm{N}$ VII dan sering bilateral, pemulihan dimulai 2-4 minggu setelah progresifitas berhenti, disfungsi autonomik, tidak ada demam saat onset gejala neurologis, tipikal CSF (albuminocytologic dissociation), hasil EMG (terdapat proses demyelinating pada saraf perifer) (Ropper et al, 2009). Dari status umum pasien dalam keadaan compos mentis, E4V5M6, pada pemeriksaan neurologis pada ekstremitas motorik ditemukan ekstremitas atas $5 \| 5$, ektremitas bawah 2\|2, pada reflex fisiologis ektremitas atas $+1 \|+1$ dan ektremitas bawah $+2 \|+2$, keempat ektremitas atrofi, dan tidak ditemukan reflex patologis pada keempat ektremitas. Dari anamnesis pasien mengaku saat hamil anak pertama tahun 2016 pada umur kehamilan 6 bulan pasien mengeluh demam, batuk, pilek dan pasien didiagnosis
ISPA. Hal ini sesuai teori etiologi dari GBS yaitu infeksi yang menyerang fungsi sensorik sampai saraf otonom sehingga GBS disebut sebagai polyneuropathy autoimmune. Dua per tiga kasus GBS didahului oleh gejala infeksi bakteri seperti Campylobacter jejuni, Mycoplasma pneumonia, infeksi virus seperti Cytomegalovirus, Epstein-Barr virus dan Zika (Torricelli, 2017; Fokke et al, 2014).

Dari riwayat penyakit sebelumnya saat hamil anak pertama pasien dirawat di ICU dengan menggunakan alat bantu nafas yang besar kemungkinan disebabkan adanya paralysis otot pernafasan. Hal ini sesuai bahwa pasien GBS hampir $70 \%$ terdapat gangguan sistem saraf otonom (aritmia jantung, dan peningkatan tekanan darah bahkan pada sebagian kasus sampai terjadinya krisis hipertensi). Lumbal pungsi untuk melihat disosiasi sito protein (tidak dilakukan) pada kasus ini padahal dari beberapa teori mengenai GBS menyatakan bahwa pemeriksaan penunjang cairan serebrospinal (CSS) dapat mendukung diagnosis bila ditemukan terdapat protein. Pada LP protein meningkat setelah gejala 1 minggu atau terjadi peningkatan pada LP serial yaitu Jumlah sel CSS $<10 \mathrm{MN} / \mathrm{mm} 3$ atau tidak ada peningkatan protein CSS setelah 1 minggu gejala dengan jumlah sel CSS: 11-50 MN/mm (Torricelli, 2017; Fokke et al, 2014). 
Tatalaksana pasien GBS pada fase akut harus di opname di rumah sakit untuk observasi ascending paralysis karena dapat mencapai otot pernafasan hanya dalam waktu 24 jam. Fungsi pernafasan di observasi untuk mencegah terjadinya gagal nafas, sehingga dapat ditangani dengan cepat. Pasien dengan progresifitas yang lambat dapat diobservasi untuk stabilisasi, sedangkan pasien dengan progresif ascending paralisis dapat diberikan Intravenous Immunoglobulin (IVIG), diberikan 2-5 hari dengan dosis IVIG 0.4 $\mathrm{g} / \mathrm{kg} /$ hari untuk 5 hari, atau dosis tinggi (1 $\mathrm{g} / \mathrm{kg} /$ hari untuk 2 hari). Alternatif yang lain plasmapheresis dan atau obat-obatan immunosuppressif.

Prognosis GBS pada kehamilan relatif baik, karena $90-95 \%$ terjadi kesembuhan tanpa gejala sisa dalam waktu 3 bulan. Kesembuhan dapat diketahui melalui pemeriksaan Nerve Conduction VelocityElektromiografi (NCV-EMG) yang hasilnya relatif normal. Sebaliknya pasien yang mendapat terapi plasmaparesis mulai saat onset, penyembuhannya dalam 4 minggu. Progresifitas penyakit lambat dan pendek, pada penderita berusia 30-60 tahun namun tidak terjadi kelumpuhan total, Angka kematian pada GBS sebesar 5\% dan kebanyakan pasien membaik pada beberapa bulan. Jika tanpa pengobatan, sekitar $35 \%$ dari pasien memiliki kelemahan residual, atrofi, hiporefleksia dan kelemahan otot wajah. Prognosis buruk pada pasien dengan usia tua yang didahului penyakit sistem Gastro Intestinal, namun bila dilihat dari tidak teraturnya pasien untuk berobat pada kasus ini maka prognosa dubia ad malam (Cheng et al, 2016; Kuwabara and Yuki, 2013).

Sundaram dkk melaporkan bahwa GBS jarang memperberat kehamilan, namun jika tidak cepat teridentifikasi dan ditangani dapat meningkatkan tingginya morbiditas pada ibu dan janin. Perawatan intensif dan infus terapi immunoglobulin (IVIG) adalah pilar utama pada manajemen pada GBS dalam kehamilan. Ahli saraf dan kandungan harus lebih perhatian akan risiko kekambuhan GBS dalam periode pasca-melahirkan. Operasi dan anestesi juga dapat menjadi pemicu GBS untuk kambuh dengan peningkatan keseluruhan sitokin pro-inflamatorik pada periode pasca melahirkan. Telah dilaporkan kasus GBS berat pada kehamilan trimester ketiga diikuti oleh kekambuhan pada periode pasca melahirkan (Meenakshi-Sundaram et al, 2014).

Kelumpuhan dari kedua ektremitas bawah akibat GBS pada kasus ini tidak mempengaruhi terhadap kehamilan karena CIDP, namun berpengaruh pada mode of delivery karena kelumpuhan pada kedua ekstremitas bawah. Kelumpuhan ini 
Guillain Barre Syndrome pada Kehamilan

Hermin Sabaruddin, Pribakti Budinurdjaja, Fakhrurrazy

membuat pasien tidak dapat mengejan dengan kuat pada persalinan bantuan vakum ekstraksi (gagal vakum) sehingga dilakukan tatalaksana seksio sesaria.

\section{KESIMPULAN}

GBS (Guillain-Barre Syndrome) tidak mempengaruhi kehamilan, namun kehamilan dapat diperberat dengan adanya GBS bila tidak cepat teridentifikasi dan ditangani dapat meningkatkan tingginya morbiditas pada ibu dan janin.

\section{DAFTAR PUSTAKA}

Cheng $Q$, Jiang GX, Fredrikson $S$, Link $H$, de Pedro-Cuesta J. 2016. Increased incidence of Guillain-Barré syndrome postpartum. Epidemiology. 9: 601-604.

Fokke C, Berg BVD, Drenthen J, Walgaard C, Doom PAV et al, 2014. Diagnosis of Guillain-Barre syndrome and Validation of Brighton Criteria. BRAIN a journal of Neurology. 137: 33-43.

Gunawan A, Goysal Y, Chalid SMT, 2004. Kelainan Neurologik pada Kehamilan. IImu Kedokteran Fetometernal. 608.

Hiraga A, Mori M, Ogawara K, Kojima S, Kanesaka T et al, 2005. Recovery Patterns and Longterm Prognosis for Axonal Guillain-Barré
Syndrome. Journal of neurology, neurosurgery, and psychiatry. 76(5): 719-722.

Kuwabara S, Yuki N, 2013. Axonal GuillainBarré syndrome: Concepts and Controversies. Lancet Neurol. 12(12):1180-1188.

Meenakshi-Sundaram S, Swaminathan K, Karthik SN, Bharathi S, 2014. Relapsing Guillain Barre Syndrome in Pegnancy and Postpartum. Annals of Indian Academy of Neurology. 17(3): 352-354.

Mori M, Kuwabara S, Yuki N. 2012. Fisher Syndrome: Clinical Features, Immunopathogenesis and Management. Expert Rev Neur other.12:39-51.

Ropper AH, Samuels MA, Klein JP, and Prasad S, 2009. Adams and Victor's Principles of Neurology $9^{\text {th }}$ edition. Mc Graw Hill Medical Ebook, USA. 1261-1270

Torricelli RPJE, 2017. Acute Muscular Weakness in Children. Arquivos de Neuro-Psiquiatria. 75(4). 248-254. Zafar MS, Naqash MM, Bhat TA, Malik GM, 2013. Guillain-barré Syndrome in Pregnancy: An Unusual Case. J Family Med Prim Care. 2(1): 9091. 